\title{
The Photonics Academy: pipeline to the future
}

Dominique F. Wilson

Dominique F. Wilson, "The Photonics Academy: pipeline to the future," Proc. SPIE 9663, Eighth International Topical Meeting on Education and Training in Optics and Photonics, 96631 U (6 October 2003); doi: 10.1117/12.2208476

SPIE Event: Eighth International Topical Meeting on Education and Training in Optics and Photonics, 2003, Tucson, Arizona, United States 


\title{
The Photonics Academy: pipeline to the future
}

\author{
Dominique F. Wilson \\ Sandia National Laboratories, P.O. Box 5800, Albuquerque, New Mexico 87185-1351 \\ telephone: 505-844-1315; fax: 505-844-1228; e-mail:dfoley@sandia.gov
}

\begin{abstract}
The Photonics Academy offers high-schoolers courses to prepare them for high-tech work in optics and photonics. Students achieve sufficient math and science proficiency to attend university or community college. Internship opportunities, tours, guest lecturers, articulated curriculum are popular program components. Enrollment is close to 200 students, $48 \%$ female and $65 \%$ Hispanic.

(C)2003 Optical Society of America

OCIS codes: (000.2060) Education
\end{abstract}

\section{Summary}

The Photonics Academy is a four-year high school curriculum, funded by the US Department of Energy/Defense Programs and sponsored by Sandia National Laboratories, that combines photonics/optics and R\&D development activities with technical organizations at the Labs. Students take technical courses at the high school level and can enroll concurrently at Albuquerque TechnicalVocational Institute or the University of New Mexico. The articulated curriculum creates a technologyfocused pathway within the high school environment. Students may begin interning at Sandia during the summer following their high school graduation and continue working while attending T-VI or UNM.

The Academy is the foundation for a comprehensive optical science \& engineering program that spans middle school through the Ph.D. level. New Mexico is unique nationally in this respect and offers students the flexibility to enter and leave the workforce at any juncture in the educational ladder.

The four-year curriculum encompasses courses in mathematics, science, computer applications, metallurgy, pre-engineering electronics, introduction to photonics, digital circuits, photonics, optics, lasers, semiconductors. A shining aspect of the program is that it does not pigeonhole students: graduates emerge with sufficient proficiency in math, science, and core courses to enter a four- or twoyear institution or proceed straightaway into the workplace.

The Photonics Academy provides a link to New Mexico's optics industry and Sandia's Microsystems S\&T and Components Center and Surety Components \& Instrumentation Center. The Center develops and applies advanced manufacturing processes in support of Sandia's primary mission of ensuring the security and reliability of the nation's nuclear weapons stockpile. Students are trained to work in the centers' design, development, or fabrication areas.

The Photonics Academy has received endorsement from the Optical Society of America (OSA) and the International Association of Optical Engineers (SPIE) and can be used as a national model. It is supported by the Center for Occupational Research \& Development, Air Force Research Laboratory, Directed Energy Professional Society, New Mexico Optics Industry Association and the Center for High Tech Materials at The University of New Mexico. It has successfully integrated -- both vertically and horizontally - educational, industrial, academic, and governmental components. These include a national laboratory; DOE/DP; a district school system; articulation of curriculum with three technical institutes; parents; the Next Generation Economy Initiative, an economic development activity; regional industry; the leading professional society; skills standards; Carl Perkins Grant; and local and national media. 